\title{
Physical Exercise and the Environment: A Danger for the Lives of Athletes and/or Those Who Practice Physical Exercises
}

\author{
Antonia Dalla Pria Bankoff ${ }^{1,2, *}$, Carlos Aparecido Zamai $^{2}$, Sonia Regina Jurado ${ }^{1}$, Odanir Guerra ${ }^{1}$ \\ ${ }^{1}$ Federal University of Mato Grosso do Sul (UFMS), Campus of Tres Lagoas, Brazil \\ ${ }^{2}$ Faculty of Physical Education (ETF), The University of Campinas, Brazil
}

Copyright $(2016$ by authors, all rights reserved. Authors agree that this article remains permanently open access under the terms of the Creative Commons Attribution License 4.0 International License

\begin{abstract}
In large cities, it is common for people to practice physical activities or exercise in large or busy streets and avenues with intense vehicle traffic. As a result, they ingest large amounts of carbon monoxide, thus constituting a great danger to both athletes and individuals who practice in this manner. There are two objectives in this study: (a) to investigate the physiological changes caused by $\mathrm{CO}$ and (b) to analyze how the physiological changes caused by $\mathrm{CO}$ influence health and performance. Material and Method: Since this is a little known topic in physical education, this paper uses exploratory research. We studied papers on physical exercise and the action of local pollutants considered inadequate for physical exercise. For such, we used the Scielo database (the Scientific Electronic Library Online - an electronic library covering a selected collection of Brazilian scientific journals) to verify these studies. The database was queried using terms registered in the Health Science Descriptors created by the Virtual Library of Health developed by the Medical Subject Headings of the U.S. National Library of Medicine, which allowed the use of common terminology in Portuguese, English, and Spanish. Results: Pollution also increases the risk of lung problems. The most significant problem with running in polluted environments is not the effect of a single day, but the repeated practice that can make the athlete more susceptible to respiratory problems, especially due to the dryness of the nasal airway.
\end{abstract}

Keywords Exercise, Environment, Pollutant, Temperature, Atmosphere

\section{Introduction}

In large urban centers, individuals frequently practice physical activities or do exercise along large avenues or streets with intense vehicle traffic. As a result, they inhaled large amounts of carbon monoxide and were thus exposed to serious health hazards. Even when invisible, pollution is a major issue in the practice of sports, as it may both impair physical performance and cause serious damage to an individual's health, including heart attacks and lung cancer $[1,2]$.

Individuals leaving their homes for a walk or a run through the streets, avenues, and parks in large cities do so with the best of intentions. However, an invisible enemy may be masking the benefit of the practice of sports in these conditions: pollution. Often unnoticed, it does not seem to interfere with the exercises. In polluted environments, the eyes are the organ that perceives the pollution, which may burn or tear up. However, researchers and experts have increasingly highlighted the risk of practicing sports in polluted areas to the body. If staying healthy is the main intention of its practitioners, the alert merits attention. For the lungs of amateur athletes, practicing in these locations corresponds to smoking two cigarettes a day. This is because the body demands more oxygen during physical activity, with the muscles, heart, and lungs working with greater intensity $[3,2]$.

To meet this demand, human bodies inhale more air and, with it, more pollutants. "When exercise becomes more intense, practitioners also begin to breathe through their mouths, allowing the entry of particle pollution into the airways which would otherwise be filtered by the nostrils. This particular pollution is absorbed by our respiratory system and interferes with the intake of oxygen by tissue and can cause inflammation in the airways." Individuals react differently to pollutants, but the symptoms identified most frequently include redness and irritation to the eyes and throat, a dry sensation in the nose and mouth, as well as exhaustion. However, the consequences that cannot immediately be seen or felt are the ones which may cause the worst damage [3].

One of the pollutants in the atmosphere greatly affecting sports performance when combined with heat and humidity 
is ozone. In one study, 10 professional high-performance athletes participated in an experiment, which involved an eight-kilometer race into four different environments. The results found that when athletes were exposed to high concentrations of ozone, heat, and humidity, their performance worsened by an average of 33 seconds. "For an elite athlete, this is a very significant deterioration," he says. According to the Minas Gerais Environmental Agency, in addition to $\mathrm{O}_{3}$, the pollutants most often found in large Brazilian cities are particulate matter (dust), sulfur dioxide $\left(\mathrm{SO}_{2}\right)$, carbon monoxide $(\mathrm{CO})$, nitrogen oxide (NOx), and hydrocarbons (HC). Especially during the winter, they are identified in quantities above adequate levels [4].

Running outdoors on the street can provide practitioners with freedom, satisfaction, and contact with nature, fresh air, and better health. Those who make this choice over going to the gym may have inverse results related to vitality. "Many who walk or run through the streets, avenues, or parks in major urban centers aim to achieve better health. However, an invisible risk may reduce the benefits from the practice of sports in these locations: pollution." Common consequences are eye irritation, redness, excessive tiredness, dizziness, and income fall. "Pollution is also responsible for the incidence of chronic bronchitis, lung diseases, allergic rhinitis, and even lung cancer, a disease that has the risk increased by about $30 \%$," he adds [4].

In general, major air pollutants which exert harmful influences on humans are: sulfur dioxide $\left(\mathrm{SO}_{2}\right)$, ozone $\left(\mathrm{O}_{3}\right)$ particulate matter (PM), carbon monoxide (CO), hydrocarbons (HCs), nitrogen oxide (NOx), volatile organic compounds, and other more toxic chemicals such as mercury, lead, benzene, nickel, acetaldehyde, polycyclic aromatic hydrocarbons (PAHs), hexavalent chromium, asbestos, and others $[5,6]$.

Thus, in urban centers, mean $\mathrm{CO}$ concentrations over an eight-hour period are usually below $20 \mathrm{mg} / \mathrm{m}^{3}$, with peaks within an hour below $60 \mathrm{mg} / \mathrm{m}^{3}$, while in environments not exposed to intense anthropogenic emissions, the concentration ranges between 0.01 and $0.23 \mathrm{mg} / \mathrm{m}^{3}$. For the purpose of comparison, see Table 1 for the amounts recommended by [6] for air quality, which are below the concentrations of $\mathrm{CO}$ often found in urban areas.

Table 1. WHO standard for maximum $\mathrm{CO}\left(\mathrm{mg} / \mathrm{m}^{3}\right)$ concentration according to exposure time.

Table is adapted by [6].

\begin{tabular}{|c|c|c|c|c|c|}
\hline Time & Yearly & 8 hours & 1 hour & $30 \mathrm{~min}$ & $15 \mathrm{~min}$ \\
\hline $\begin{array}{c}\mathrm{CO} \\
\mathrm{mg} / \mathrm{m}^{3}\end{array}$ & $0.5-7$ & 10 & 30 & 60 & 100 \\
\hline
\end{tabular}

\section{About Carbon Monoxide}

Carbon monoxide (CO) is a molecule with toxic properties that have been known for centuries. It belongs to the group of gaseous pollutants. Carbon monoxide is an odorless, colorless, and tasteless gas. This pollutant is produced both by natural and anthropogenic processes.
Examples of natural sources of emissions include spontaneous forest fires, volcanic eruptions, and chlorophyll decomposition. In relation to anthropogenic sources of emissions, some examples include energy production by thermal power stations, chemical industries, petroleum processing industries, and mainly automotive vehicles $[7$, 8].

The atmosphere of large commercial and industrial centers daily receives tons of carbon monoxide produced by incomplete combustion reactions that are processed in vehicle engines and industrial boilers. The major problem with carbon monoxide lies in the fact that it is an extremely poisonous gas, which interferes in the breathing process in relation to hemoglobin, a substance present in red blood cells. The molecular mass of hemoglobin is approximately 66,000 units, which indicates that it is built by large molecules. Included in its composition are carbon atoms, hydrogen, oxygen, nitrogen, sulfur, and four $\mathrm{Fe}^{2+}$ ions, as per [9].

When we breathe, oxygen $\left(\mathrm{O}_{2}\right)$ molecules connect to the iron ions from the hemoglobin molecules $(\mathrm{Hb})$. The product of this reaction is oxy-hemoglobin $\left(\mathrm{HbO}_{2}\right)$.

$$
\mathrm{Hb}+\mathrm{O}_{2} \Rightarrow \mathrm{HbO}_{2}
$$

Oxy-hemoglobin, carried through the blood, comes into contact with all cells in the body. Oxygen is then released and enters the cells to participate in chemical reactions that occur within them. Hemoglobin is again free, and it may connect to other oxygen molecules. This substance, therefore, transports oxygen within the vertebrate's organism. Carbon monoxide, through a similar process, also reacts with hemoglobin, creating carboxyhemoglobin:

$$
\mathrm{Hb}+\mathrm{CO} \Rightarrow \mathrm{HbCO}
$$

When there is carbon monoxide in the air we breathe, a form of competition occurs in the blood between $\mathrm{CO}$ and $\mathrm{O}_{2}$ for the hemoglobin molecules. The problem caused by this competition is the fact that the $\mathrm{Fe}^{2+}$ ions connect more strongly to $\mathrm{CO}$ than to $\mathrm{O}_{2}$. Thus, the hemoglobin molecules that react with $\mathrm{CO}$ are released less frequently and lose their function as an oxygen carrier, and the hemoglobin is then said to be inactive [9].

The higher the concentration of $\mathrm{CO}$ in the air inhaled, the higher the amount of inactive hemoglobin and, as a result, the more severe the health damage. The percentage of inactive hemoglobin grows as the concentration of $\mathrm{CO}$ increases: a concentration of $50 \mathrm{ppm}$ (parts per million) of $\mathrm{CO}$ deactivates $7 \%$ of hemoglobin and causes vision problems. However, the tables do not show how much hemoglobin is deactivated when there is, for instance, 70 ppm of CO in the air [9].

The damaging role of carbon monoxide has been known for hundreds of years, and the prevailing idea is that it is only a toxic agent, a pollutant, or a waste product. For over a century, the effects of high concentrations of $\mathrm{CO}$ were studied intensely, and it was shown that intoxication might be fatal. This is why it is referred to as the "silent killer" $[10$, 11]. However, living organisms create $\mathrm{CO}$ as part of their 
normal cellular functions, and its production seems to increase during pathological conditions. Is $\mathrm{CO}$ a mere toxic agent or a simple residue from cellular activity [12]?

Gases considered pollutants are those emitted during the incomplete combustion of materials that contain carbon, such as petroleum and coal derivatives. In daily life, gasoline, diesel, and ethanol-powered vehicles are the major sources of air pollutants. One of these gases is carbon monoxide. It is interesting to note that $\mathrm{CO}$ is highly damaging to human health, since it is 250 times more likely than $\mathrm{O}_{2}$ to bind to hemoglobin, which is responsible for transporting oxygen into tissues. When this bind takes place, a compound called carboxyhemoglobin is created $(\mathrm{COHb})$, hindering $\mathrm{O}_{2}$ fixation and the transportation to the organism's cells [13].

Therefore, it is during exercise that the body needs oxygen the most. If air with carbon monoxide is inhaled during these periods, the body's capacity to transport oxygen will be compromised, directly affecting physical performance and breathing, among other functions. Sulfur dioxide $\left(\mathrm{SO}_{2}\right)$ is another gaseous pollutant created by automotive vehicles, emitted mainly by heavy vehicles powered by diesel, such as trucks and buses [14].

\section{Recommendation [14]:}

Do not practice activities during high level of pollution (7 a.m. -10 a.m. and 4 p.m.-7 p.m.), due to traffic;

As a rule, the best time to practice outdoor exercises are before 7 a.m. and after 8 p.m;

Remember that ozone spikes take place between 11 a.m. and 5 p.m. in areas with trees, such as parks;

Choose streets that are further away from traffic and mainly stay away from streets occupied by trucks and buses;

If you are exercising in places where there are major emission of pollutants, do not exert yourself and breathe through your nose, exhaling through your mouth, to reduce contamination;

When the weather is hot, avoid exercising between 10a.m. and 4p.m., and during the winter, watch out for thermal inversion. The rule is not to exercise when the air humidity is excessively low, such as during the winter, when the air is usually drier.

If you have to choose between an avenue and a park, choose the park;

Always carry a bottle of water with you.

Another important factor in the practice of physical exercise is thermal regulation. Normal body temperature fluctuate several degrees throughout the day as a response to physical exercise, emotions, and room temperature variations. Thermal regulation performs an important role in the homeostatic balance of the body, and any failure may lead to death. An individual is able to tolerate a deep reduction of $10^{\circ} \mathrm{C}$ in the body temperature; however, we are only able to tolerate a temperature increase of $5^{\circ} \mathrm{C}$. During the last 20 years, many American football players have died from thermal stress during training or competitions $[1,15]$.
Keeping in mind that $\mathrm{CO}$, as an air-polluting agent, primarily interferes in the air quality in large urban centers, this study aims at discussing, based on specialized scientific literature, the influence of this pollutant on physical activity, since it directly and indirectly interferes in the physiological parameters of systems in the human organism [6]. After all, the volume of air inhaled per minute, also known as respiratory minute volume (VE), may increase up to 15.7 times $^{2}$ in a sedentary person during exercise, thus increasing the amount of air as well as pollutants inhaled [16].

In addition, under a variety of physical and environmental conditions, the balance between the production and loss of heat, resulting from the action of thermal regulating centers, maintains body temperature at stable level, which is around $37^{\circ} \mathrm{C}$. In most cases, the organism does not need to turn to exceptional thermal-regulating actions to maintain balance in its core temperature. However, when the body is exposed to thermal situations of extreme cold or heat, which exceeds thermal comfort limits, these actions are triggered to keep the internal heat stability, preventing functional changes that would be damaging to the organism $[15,16]$.

\section{Objectives}

In this context, the outlined objectives of this work are: (a) to investigate the physiological changes caused by $\mathrm{CO}$; (b) to analyze physiological changes caused by $\mathrm{CO}$ that influence health and performance through literature on this issue that is so important to the field of physical education and sports.

\section{Material and Method}

In order to achieve the objectives described in this exploratory study, the methodology will be a review of the literature. We studied papers on physical exercise and the action of local pollutants considered inadequate for physical exercise. For such, we used the Scielo database to verify these studies.

The database was queried using terms registered in the Health Science Descriptors created by the Virtual Library of Health developed by the Medical Subject Headings of the U.S. National Library of Medicine, which allowed us to use common terminology in Portuguese, English, and Spanish.

\section{Results}

\section{Research shows}

The studied research showed that race in environment that was hot, humid, and polluted by ozone worsens completion times of athletes when compared to those who exercised in ideal conditions. The heart rate also increases under the influence of pollution. In addition, blood and nasal secretion tests of the participants showed inflammatory damage to the 
lining of the respiratory tract and oxidative stress markers, better known as free radicals [5]. Another very interesting factor that is harmful to the body is the exposure to pollution in the form of carbon monoxide and ozone, in conjunction with heat and humidity, which leads to a drop in performance of the runners and results in premature damage to the mucous membrane that lines the respiratory tract [4].

[1] Reports that individuals who practice sports and exercise in areas with high temperatures, humidity, and pollution have increased risk factors associated with respiratory problems and blood pressure. [17] Reports, through the results obtained in experiment, that use of vitamins $\mathrm{C}$ and $\mathrm{E}$ as supplements for their antioxidant properties can minimize the impact of pollution on health and athletic performance. [12] Reports that in a year, the volume of air inhaled per minute, also known as respiratory minute volume $\left(\mathrm{V}_{\mathrm{E}}\right)$, may increase by 15.7 times $^{2}$ in a sedentary person when performing exercise, thereby increasing the amount of air and consequently the pollutants inhaled. The gases present in pollution compete with oxygen in the blood. This makes the athlete more prone to hypertension, heart attack, and stroke (CVA). Some studies also evaluated the possibility of ozone worsening cholesterol deposits in the arteries, compromising heart health even further [17]. During autumn and especially during the winter in Brazil, the air quality gets worse. The dry climate, low temperature, and low amounts of wind favor the formation of large masses of gases that are health hazards, such as nitrogen oxide, carbon monoxide, and ozone, in addition to large quantities of particles released by cars, buses, and motorcycles. Continuous exposure to all this pollution triggers inflammation throughout the body and enhances the oxidation process of the cells, or degeneration. This oxidation is responsible for the aging of skin and organs as well as cancer $[4,17]$.

Pollution also increases the risk of lung problems. In addition, the greatest problem with racing in polluted environments is not the effect of a single day, but the repeated practice that can make the athlete more susceptible to respiratory problems, especially due to the drying of the airways $[1,18]$.

\section{Discussion}

Discussing physical activity, exercise, and sports and their benefits is not difficult, because they greatly contribute to an improved quality of life and to change habits and lifestyle for the better, in addition to playing a significant role in physiological changes that improve the entire functioning of organic systems. However, when the practice takes place at high temperatures and in humid, polluted environments, some damage to organ systems may take place, as reported by the literature studied in this work [18].

[1] The literature also reports that the ideal is to practice exercise outdoors in green areas, preferably away from local pollution, and not to forget to intake fluid, preferably water.
In Brazil, summer time takes place from October to February, where temperature often reaches 35 degrees on average, with some states showing higher temperatures. Even so, people continue performing outdoor physical activities at high temperatures and in areas that are polluted. These conditions provoke greater risks to the health and quality of life of practitioners, bearing in mind that the sun does not discriminate whether it is the summer or not, and individuals always have the same scheduled routines.

In terrestrial organisms, heat from the external environment as well as heat generated by their vital functions causes an inevitable temperature increase. High temperature causes vital enzyme and protein denaturation and consequently affects the metabolism, and it is through transpiration that some of these organisms eliminate part of this heat. The water presented internally in living beings is heated and rises to the surface (through glands in vertebrates or stomas and pores in plants, or through urine and other specialized structures) carrying with it the internal heat and expelling it from the body [14]. Animals that are unable to transpire have difficulty in maintaining their metabolism at high rates, as well as trouble surviving in extreme temperatures, and thus maintain slow and precise motions during the fresher times of the day or even adopt an aquatic lifestyle. In some mammals, such as human beings, transpiration occurs as the skin sweats. In addition to eliminating excessive heat from inside the body, it also cools down the surface as the skin comes into contact with air currents. Sweating in humans is promoted by sweat glands, which, aside from water, eliminate minerals, and other dangerous or unnecessary compounds presented in the blood, such as uric acid [16]. Excessive sweating is called hyperhidrosis.

The authors' studies are unanimous in reporting that there is a reduction in physical performance in high temperatures and polluted environments. Individuals who exercise in these conditions are more vulnerable to respiratory problems, which influence important physiological requirements of physical performance for the practice of physical activities and sports. They also state that carbon monoxide may cause tissue hypoxia and thus reduce the oxidative reactions.

\section{Conclusions}

The practice of physical exercise in the form of running in polluted locations and at high temperatures in the literature compiled showed:

A reduction in performance;

A reduction in performance in relation to the athlete's time;

That carbon monoxide (CO) adversely affects the athlete's performance, since it has properties that alter physiological aspects;

That the main effects of carbon monoxide (CO) exposure are due to its high potential to alter the transportation of oxygen in hemoglobin, myoglobin, and the mitochondria, 
causing tissue hypoxia and a consequent reduction of oxidative reactions;

High temperatures and polluted environment cause excessive sweating;

Health practitioners are more vulnerable to breath problems, influencing important physiological properties required for physical performance in the practice of physical activities and sports;

Exercise performed for prolonged period in hot and polluted environment can alter blood pressure levels on a daily basis.

\section{REFERENCES}

[1] BANKOFF, ADP. Fatores Importantes sobre Concepções Morfológicas. Revista da Associação dos Professores de Educação Física de Londrina, Londrina PRf, v. 14, n.1, p. 62-69, 1999.

[2] BANKOFF, ADP ; ZAMAI, CA; JURADO,SR; GUERRA,O. Physical exercise and the environment: a danger for the lives of athletes and/or those who practice physical exercises. DUST 2014, Castelanetta de Marina, Itália, junho 2014, p.143.

[3] DA SILVA, MG.Poluição pode prejudicar atividades físicas: entenda os riscos.http://sites.uai.com.br/app/noticia/saudeple na/noticias/2013/05/20/noticia_saudeplena,143402/poluicaopode-prejudicar-atividades-fisicas-entenda-os-riscos.shtml. Acesso em 22 de Agosto de 2014.

[4] RESENDE, R. Poluição e atividade física: Problema pode afetar o desempenho e a saúde dos corredores. http://www.suacorrida.com.br/saude/poluicao-e-atividades-fi sicas/ Acesso em 18 de Agosto de 2014.

[5] SEINFELD, JH; PANDIS, SN. Atmospheric Chemistry and Physics: from air pollution to climate change. Toronto: Wiley Interscience, 1998.

[6] LORA, ES. Prevenção e controle da poluição nos setores energético, industrial e de transporte. Brasília: ANEEL, 2000.
[7] WHO (World Health Organization).Guidelines for air quality. Geneva, 1999.

[8] BÖHM, GM. Como os principais poluentes provocam doenças. Available from: saudetotal.com/saude/doencpol/do encpol.htm, [c.1996].

[9] ELTON, WZ. Unidades Modulares de Química, v. II. Gráfica e Editora Hamburg, São Paulo, Centro de ensino de Ciência de São Paulo, 1986.)

[10] WU L WANG, R. Carbon monoxide: endogenous production, physiological functions, and pharmacological applications. Pharmacology Rev 2005; 57:585-630.

[11] OTTERBEIN, LE. The evolution of carbon monoxide into medicine. RespirCare 2009; 54:925-932.

[12] SAÚTIL, RG. Exercícios Físicos, poluição e altas temperaturas: Risco a saúde do homem. http://www.sautil.co m.br/saude-para-voce/saude-respiratoria/conteudo/poluicaoe-atividade-fisica. Accessed: January 02, 2014.

[13] MCARDLE, WD; KATCH, F L; and KATCH, VL; HELEN, E. K. Essentials of exercise physiology, 2nd ed, Philadelphia: Lippincott Williams \& Wilkins; 2006.

[14] WILMORE, JH; COSTILL, DL. Physiologyofsport and exercise. Champaign: Human Kinetics, 1994.

[15] GALLOIS, NS P. Análise das condições de stress e conforto térmico sob baixas temperaturas em indústrias frigoríficas de Santa Catarina. 2002. 140fls. Dissertação (Mestrado em Engenharia de Produção) - Universidade Federal de Santa Catarina. Florianópolis, SC: UFSC, 2002.

[16] GUYTON, AC; HALL, J. E..Tratado de fisiologia médica. 11. ed.. Rio de Janeiro, RJ: Guanabara Koogan, 2006.

[17] DINIZ, T. Exercício físico e poluição. http://virusdaarte.net/e xercicios-fisicos-e-poluicao/ Acesso em 24 de junho de 2014.

[18] BANKOFF, ADP; ZAMAI, CA. JURADO, SR.; GUERRA, O. Physical Exercise and the Environment: A Danger for the Lives of Athletes and/or Those Who Practice Physical Exercises. In DUST 2014, Castelaneta de Marina, Itália, 07 a 11 jun.2014. 